\title{
Environmental Factors Supporting Mangrove Ecosystem in Semarang-Demak Coastal Area
}

\author{
Andin Irsadi $^{1,2^{*}}$, Sutrisno Angggoro ${ }^{3}$, and Tri Retnaningsih Soeprobowati ${ }^{4,5}$ \\ ${ }^{1} \mathrm{Ph} . \mathrm{D}$ Program of Environmental Studies, School of Postgraduate Studies, Diponegoro University, Semarang - Indonesia \\ ${ }^{2}$ Department of Biology, Faculty of Mathematics and Natural Sciences, Semarang State University, Semarang - Indonesia \\ ${ }^{3}$ Faculty of Fisheries and Marine Sciences, Diponegoro University, Semarang - Indonesia \\ ${ }^{4}$ Department of Biology, Faculty of Sciences and Mathematics, Diponegoro University, Semarang - Indonesia \\ ${ }^{5}$ School of Postgraduate Studies, Diponegoro University, Semarang - Indonesia
}

\begin{abstract}
Since the 1990s, the Semarang-Demak coastal area experienced abrasion. To protect abrasion, there have been many attempts such as planting mangroves, in which its development has shown success. The purpose of this study was to analyze environmental factors that play a role in the growth of mangroves ecosystem in the Semarang-Demak coastal area. Mangrove data were obtained by field studies using the transect method in three coastal areas. Each station is determined by the next station with five plots of size $20 \mathrm{~m}$ x $20 \mathrm{~m}$. Data on supporting environmental factors are measured in each area including temperature, salinity, $\mathrm{pH}$, light intensity, nutrients, and rainfall. Based on the results of analysis and calculations, the order of important values from large to small is A. marina, A. alba, R. mucronata, S. casseolaris, and R. stylosa, while environmental factors still fulfill mangrove growth. However, it needs to be aware of the increase in waves and temperatures that could threaten the survival of mangroves.
\end{abstract}

Keywords: Environmental factor; mangrove; coastal area; Semarang-Demak.

\section{Introduction}

The Semarang-Demak North Coast is an area that has experienced abrasion and has undergone a change in coastline [1]. This coastline change occurs in the Semarang area [2] and also in the coastal areas of Demak $[3,4]$. Naturally, the change in coastline at the Semarang-Demak coastal area is caused by the tidal wave that erodes the coast, as well as human factors by changes in land use [5]. As a result, the destruction of the coast of Semarang and Demak had induced seawater intrusion into the land. Changes in shoreline caused by erosion can be prevented by the presence of natural coastal protectors, namely mangroves $[6,7]$.

Mangroves are forest types consisting of all plants along the coast or river estuary which are affected by tides and interacting with their environment both biotic and abiotic. Mutual interaction and interdependence between components in mangrove forests are called the mangrove ecosystem. However, the area of mangrove forests in the world has decreased by $30-50 \%$ in the last half-century due to coastal development, expansion of pond development and excessive logging [8]. Many efforts have been made to restore mangrove forests, including planting program.

Efforts to plant mangroves at Semarang-Demak coastal area have been carried out to increase mangrove area $[1,9]$. The success of the planting program is supported by environmental factors in the mangrove ecosystem. For this reason, this study was conducted in order to analyzed mangrove diversity and the dynamics of environmental factors that play an important role in mangrove growth, a baseline on the management of sustainable mangroves in Semarang-Demak coastal area.

\section{Method}

This research was conducted from June to December 2018. The research site was located at Semarang-Demak coastal area which was divided into three research sites. Administratively, the three sites are located in the Timbulsloko village, Bedono Village and Trimulyo Village. The environmental parameters observed in this study included salinity, air temperature, water $\mathrm{pH}$, soil $\mathrm{pH}$, rainfall, and light intensity. Environmental data in salinity, water $\mathrm{pH}$, soil $\mathrm{pH}$, and light intensity were directly observed in the field. While for rainfall and air temperature data were using data from BMKG.

The site of the study was subjectively determined based on the density of mangroves for subsequent transects. The length of transect is 100 meters from the coast to land. Samples were taken in each area at a distance of 0-20 m, 21-40 m, 41-50 m and so on. The next is determining the sampling area. Vegetation data

\footnotetext{
*Corresponding author: andinirsadi@students.undip.ac.id
} 
were taken by the quadratic method with a size of $20 \mathrm{x}$ 20 meters for observation of trees/poles, then they were made into smaller plots $(5 \times 5$ meters $)$ to measure saplings. For seedlings, the data were collected from each plot measuring $2 \times 2$ meters. Furthermore, dominance and relative dominance are calculated, relative density and density, relative frequency and frequency, important value, and diversity index.

\section{Results and Discussion}

Based on the results of the study, five types of mangroves were found in Semarang-Demak coastal area, namely two from the genus the Avicennia namely Avicennia marina (Forsk.) Vierh, Avicennia alba Blume., two from the Rhyzophora genus namely Rhyzophora stylosa Griff., Rhyzophora mucronata (Lamk.) and one from the Sonneratia genus namely Sonneratia casseolaris (L.) Engl. [1]. In each research site, there are different mangrove compositions. However, the composition of mangroves found in Semarang-Demak coastal area is different compared to the mangroves found in the coastal city of Semarang in terms of species. The mangroves that can be found in Semarang coast include $A$ alba, A marina, Brugueira cylindrical, $R$ apiculata, $R$ mucronata, $R$ stylosa and Sonneratia caseolaris [10]. The complete distribution of mangroves in Semarang-Demak coastal area is presented in Table 1.

In Table 1 , it can be seen that the distribution of $A$. marina mangroves at Timbulsloko, Bedono and Trimulyo, S. casseolaris was only found in Trimulyo. This shows that there are not many mangrove species found in Semarang-Demak coastal area, while the most easily found mangrove species is A. marina. Based on the calculation of the diversity index in the entire study area, the research sites have a low diversity index (Table 2.) and A. marina has the highest important value (Fig. 1).

Based on the Table. 2, it can be seen that in general, the research sites had a low diversity index $\left(\mathrm{H}^{\prime}<1\right)$, except for the Timbulsloko location which had a moderate diversity index. For the calculation of important values for each type, A. marina has the highest important value (Fig. 1).

Table 1. Distribution of mangrove species in Semarang-Demak coastal area [1]

\begin{tabular}{|c|c|c|c|c|c|c|c|}
\hline \multirow{3}{*}{$\begin{array}{l}\text { Species } \\
\text { Name }\end{array}$} & \multirow{2}{*}{\multicolumn{3}{|c|}{$\frac{\text { Timbulsloko }}{\text { area }}$}} & \multirow{2}{*}{\multicolumn{2}{|c|}{$\frac{\text { Bedono }}{\text { area }}$}} & \multirow{2}{*}{\multicolumn{2}{|c|}{$\frac{\text { Trimulyo }}{\text { area }}$}} \\
\hline & & & & & & & \\
\hline & 1 & 2 & 3 & 1 & 2 & 1 & 2 \\
\hline $\begin{array}{l}\text { Avicennia } \\
\text { marina }\end{array}$ & $\sqrt{ }$ & $\sqrt{ }$ & $\sqrt{ }$ & $\sqrt{ }$ & $\sqrt{ }$ & $\sqrt{ }$ & $\sqrt{ }$ \\
\hline $\begin{array}{l}\text { Avicennia } \\
\text { alba }\end{array}$ & $\sqrt{ }$ & $\sqrt{ }$ & $\sqrt{ }$ & - & - & $\sqrt{ }$ & $\sqrt{ }$ \\
\hline $\begin{array}{c}\text { Rhyzophora } \\
\text { stylosa }\end{array}$ & - & - & $\sqrt{ }$ & - & - & - & - \\
\hline $\begin{array}{c}\text { Rhyzophora } \\
\text { mucronata }\end{array}$ & $\sqrt{ }$ & - & $\sqrt{ }$ & $\sqrt{ }$ & $\sqrt{ }$ & $\sqrt{ }$ & - \\
\hline Sonneratia & - & - & - & - & - & $\sqrt{ }$ & - \\
\hline
\end{tabular}

\begin{tabular}{|c|c|c|c|c|c|c|c|}
\hline casseolaris & & & & & & & \\
\hline Note: $\sqrt{ }=$ found $-=$ not found
\end{tabular}

Table 2. Summary of diversity index in all research sites

\begin{tabular}{|l|r|r|}
\hline \multicolumn{1}{|c|}{ Area } & H' of Tree & H' Stakes and Poles \\
\hline Timbulsloko 1 & 0.68 & 0.68 \\
\hline Timbulsloko 2 & 0.98 & 0.98 \\
\hline Timbulsloko 3 & 1.04 & 1.04 \\
\hline Bedono 1 & 0 & 0.67 \\
\hline Bedono 2 & 0.67 & 0.26 \\
\hline Trimulyo 1 & 0.66 & 0.61 \\
\hline Trimulyo 2 & 0.37 & 0.50 \\
\hline
\end{tabular}

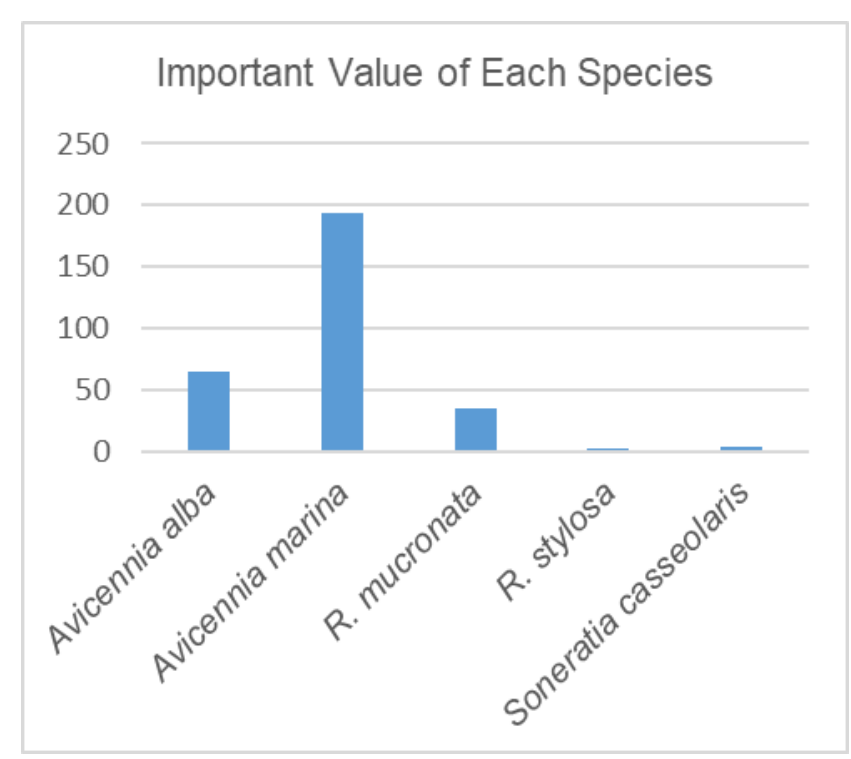

Fig. 1. The importance of each type of mangrove in SemarangDemak coastal area

Fig. 1 shows that $A$. marina has the highest important value. This indicates that $A$. marina is more dominant than other species. The dominance of $A$. marina shows that type $A$. marina has a good ability to utilize solar energy, nutrients/minerals and water and the ability to compete with other species. Besides that, morphologically $A$. marina has the root structure of pneumatophores and the presence of salt glands as a tool to support the adaptability to the environment that is not profitable for example land with high salt content [11].

Eco physiologically, the adaptation process of $A$. marina in unfavorable conditions is through three stages: 1) A. marina performs screening through the root part to avoid excessive salt absorption, 2) A. marina secretes salt that enters the body part quickly (translocation), 3) A. marina stores excess salt in the bark or old leaves and then defoliates [12-14]. In addition to the existence of supporting organs in A. marina, the factors that contribute to the survival of the A. marina are land suitability and supporting environmental factors for mangrove growth [15].

There are four main factors that determine the spread of mangrove plants, 1) the frequency of tidal currents, 2) salinity, 3) groundwater, 4) temperature [16]. Based on the identification of environmental factors carried out in the field, it was found that the $\mathrm{pH}$ of the water at the 
location of mangrove growth tended to be from acid to base (6.6-8.4), while the soil $\mathrm{pH}$ ranged from 4.8-7.3 (acid to normal). This shows that the land where the mangrove grows is an area with a good frequency of tidal currents because the soil which is often submerged in water will make the soil $\mathrm{pH}$ tend to become acidic [17].

The condition of the soil with an acid to base conditions will affect the growth of mangroves due to the availability of nutrients contained in the soil. The availability of nutrients will also affect the diversity of mangroves because each type of mangrove has the ability to adapt to soil $\mathrm{pH}$ and the availability of different nutrients so that the type of mangrove that has the ability to the environment will be able to develop.

The sites of the study show that A. marina is a type that is able to develop well because of its adaptability to the environment. In addition, the $A$. marina has an extensive root system and a large number of glands that are capable of secreting salt, so that the A. marina is able to adapt to high salinity. This ability includes the presence of roots that are able to separate salt levels. The process of salt separation occurs in the process of evaporation or transpiration in the leaves, as a form of adaptation [16, 18]. The evaporation process will take place well if it is supported by the appropriate ambient temperature. In addition to helping the transpiration process, temperature also affects photosynthesis.

In addition to the ability to adapt to land conditions, the type of mangrove also requires sufficient light intensity for photosynthesis. Based on measurements in the field, the light intensity ranges from 127-3400 lux, which indicates that the research site supports photosynthesis so that it is still suitable for mangrove growth. The process of photosynthesis will take place well if the conditions of the air temperature and humidity of the environment are supportive [13]. However, if there is an increase in high temperatures, it will reduce the solubility of oxygen so that it can reduce the availability of dissolved oxygen.

Water temperature is also an important factor that determines the life of mangroves. The temperature that limits the life of mangroves is the low temperature and seasonal temperature range. A good temperature for mangrove life is not less than $20^{\circ} \mathrm{C}$, while the seasonal range of temperatures does not exceed $5^{\circ} \mathrm{C}$, high temperatures $\left(>40^{\circ} \mathrm{C}\right)$ tend not to affect the growth and/or life of mangroves [16]. The results of the measurement of water temperature ranged from $24^{\circ} \mathrm{C}$ $34^{\circ} \mathrm{C}$ and the air temperature in the field ranged from $280^{\circ} \mathrm{C}-390^{\circ} \mathrm{C}$. This indicates that the coastal area of Semarang-Demak still supports mangrove growth.

The results of the analysis of land and environment in the form of materials $\mathrm{N}, \mathrm{P}, \mathrm{K}$ show that the field conditions are still within the limits of adequacy and conditions of humidity, air temperature and $\mathrm{pH}$ at the research site are factors that support mangrove growth. Adaptability and carrying capacity of the environment is an important factor in the evolution of mangroves [19] because the optimal carrying capacity of the environment will be an important factor in the process of mangrove growth.

The physical structure of the soil at the research site contains nutrients needed for plant growth. The results of the analysis of soil samples carried out from June 2018 to December 2018 shows that soil texture at the study site consisted of sand between $0-43 \%$, dust $2-99 \%$, and clay $1-97 \%$.

This condition shows that the three research sites are sedimentary soils dominated by dust and clay which have a strong resistance to waves [20]. This situation is one of the causes of easy abrasion due to sea waves.

Ocean wave data in 2013-2017 showed an increasing trend [1]. While the air temperature data in SemarangDemak coastal area also tends to increase (Fig. 2.).

Besides the air temperature. Other environmental factors that support mangrove growth are rainfall. The rain that occurs in an area can be an important factor because it can affect the humidity of an area. Environmental humidity will affect the organism to carry out life activities. On the other hand, high rainfall can be a trigger for erosion in an area. Based on measurements in the field, it shows that rainfall tends to increase (Fig. $3)$.

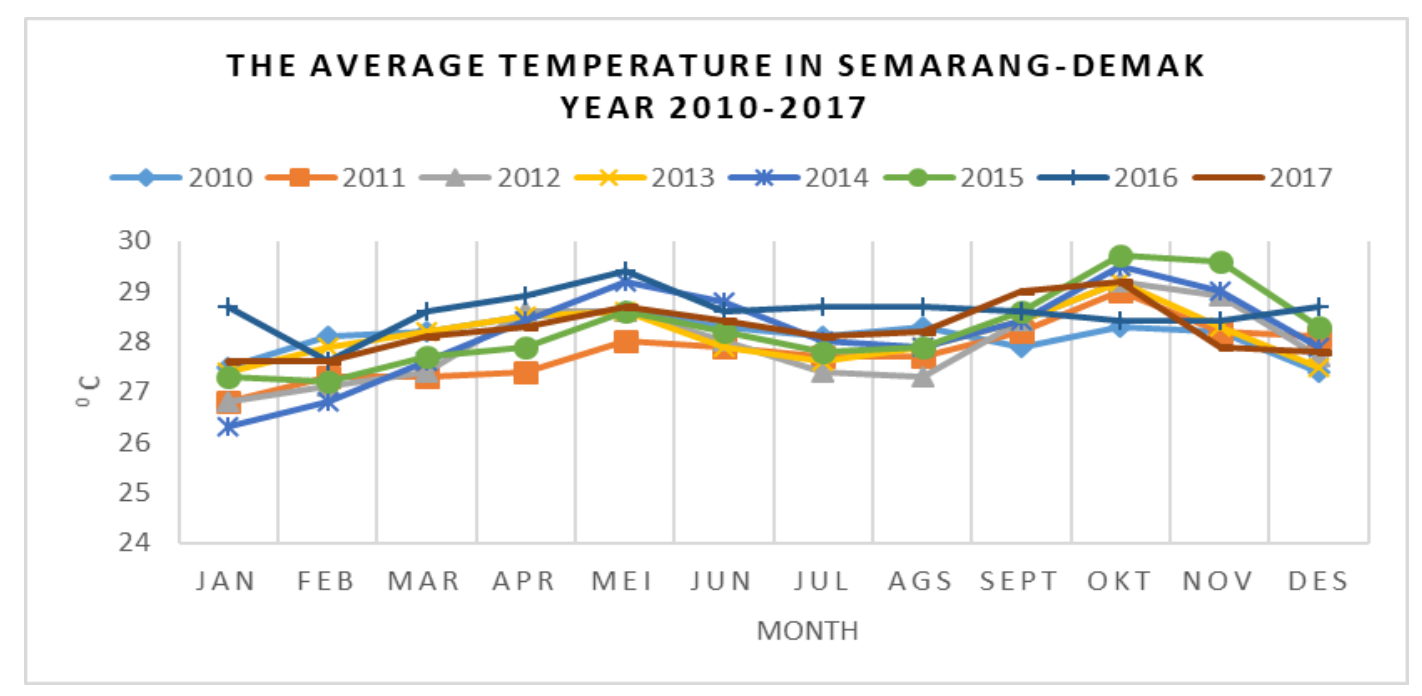

Fig. 2. The average temperature in Semarang-Demak Year 2010-2017 


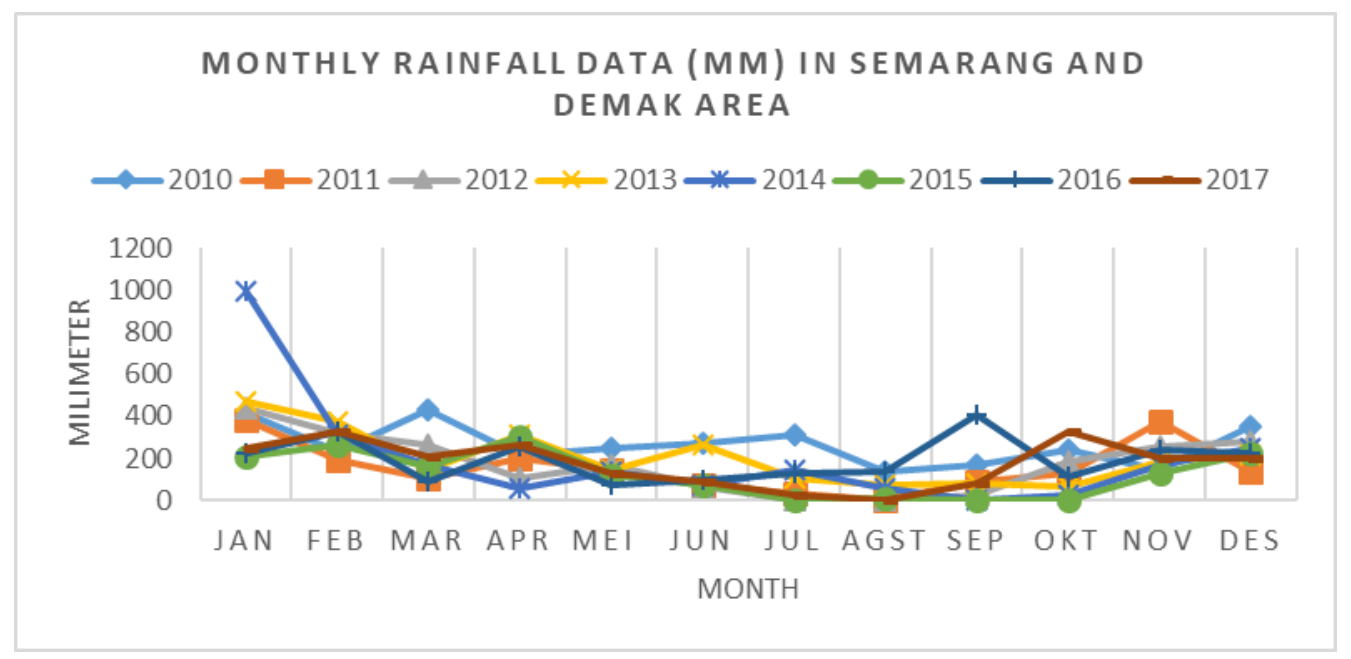

Fig. 3. Monthly Rainfall Data (mm) in Semarang-Demak Area

\section{Conclusion}

Based on the research that has been done, it can be concluded that four environmental factors (frequency of tidal currents, salinity, ground water, and temperature) in Semarang-Demak coastal area still support mangrove growth. However, wave and rainfall need attention because there is a tendency to experience in increase which can be a cause of abrasion. Five mangroves species are found in Semarang-Demak coastal, namely A. marina, A. alba, R. mucronata, R. stylosa and $S$. casseolaris.

\section{References}

1. A. Irsadi, S. Anggoro, T.R. Soeprobowati, M. Helmi, A.S.E. Khair, Shoreline and Mangrove Analysis along Semarang-Demak for Sustainable Environmental Management, Jurnal Pendidikan IPA Indonesia 8, 1-11 (2019)

2. S. Parman, Deteksi Perubahan Garis Pantai melalui Citra Penginderaan Jauh di Pantai Utara Semarang Demak, Jurnal Geografi 7 (2010)

3. M.A. Marfai, Preliminary Assessment of Coastal Erosion and Local Community Adaptation in Sayung Coastal Area, Central Java-Indonesia, Quaestiones Geographicae 31, 47-55 (2012)

4. K. Ervita, M.A. Marfai, Shoreline Change Analysis in Demak, Indonesia. Journal of Environmental Protection 8, 940-955 (2017)

5. A. Irsadi, S. Anggoro, T.R. Soeprobowati, Analisis Penggunaan Lahan di Sekitar Mangrove untuk Pengelolaan Lingkungan Pesisir Semarang Berkelanjutan, Prosiding Seminar Nasional Pendidikan Biologi dan Biologi, Jurusan Pendidikan Biologi, Fakultas MIPA, Universitas Negeri Yogyakarta (2017)

6. D.M. Alongi, Mangrove forest: resilience, protection from tsunamis and response to global climate change, Estuar coast Shelf Sci 76, 1-13 (2018)
7. B. Blankespoor, S. Dasgupta, G.M. Lange. Mangroves as Protection from Storm Surges in a Changing Climate, Policy Research Working Paper 7596 (2016)

8. D.C. Donato, J.B. Kauffman, R.A. Mackenzie, A. Ainsworth, A.Z. Pfleeger, Whole-island carbon stocks in the tropical Pacific: Implications for mangrove conservation and upland restoration, Journal of Environmental Management 97, 89-96 (2012)

9. M.A. Chafid, R. Pribadi, A.D.S. Anugroho. 2012. Kajian Perubahan Luas Lahan Mangrove di Desa Bedono Kecamatan Sayung Kabupaten Demak Menggunakan Citra Satelit Ikonos Tahun 2004 dan 2009, Journal of Marine Research 1, 167-173 (2012)

10. E.D. Hastuti, S. Anggoro, R. Pribadi. Dinamika Kondisi Struktur Komunitas Vegetasi dan Kualitas Fisika-Kimia Lingkungan Di Kawasan Hutan Mangrove Kota Semarang, Jurnal Lingkungan Tropis. 6, 61-71 (2012)

11. N.M. Heriyanto, E. Subiandono, Composition and Structure, Biomass, and Potential of Carbon Content in Mangrove Forest At National Park Alas Purwo, Jurnal Penelitian Hutan dan Konservasi Alam. 9, 023-032 (2012)

12. Murdiyanto, Mengenal, Memelihara dan Melestarikan Ekosistem Bakau, Direktorat Jenderal Perikanan Tangkap Departemen Kelautan dan Perikanan: Jakarta (2013)

13. E. Subiandono, M. Bismark, N.M. Heriyanto, Kemampuan Avicennia marina (Forsk.) Vierh. Dan Rhizophora apiculata Bl, Dala penyerapan polutan logam Berat. Jurnal Penelitian Hutan dan Konservasi Alam 10, 93-102 (2013)

14. N.K.T. Martuti, B. Widianarko B. Yulianto, Translocation and Elimination of $\mathrm{Cu}$ in Avicennia marina, Pertanika Journal Tropical Agricultural Science 40 (2), 285 - 294 (2017)

15. B. Suprakto, Soemarno, Marsoedi, D. Arfiati, Development of mangrove Conservation Area Based on Land Suitability and Environmental Carrying Capacity (Case Study from Probolinggo 
Coastal Area, East Java, Indonesia), International Journal of Ecocsystem, 4(3), 107 - 118 (2014)

16. Supriharyono, Pelestarian dan Pengelolaan Sumberdaya Alam di Wilayah Pesisir, Gramedia Pustaka Utama: Jakarta (2002)

17. Nursal, Y. Fauziah, Alzukri, Komposisi dan Struktur Vegetasi Strata sapling di Kawasan Hutan Wisata Rimbo Tujuh Danau Kabupaten Kampar Provinsi Riau, Jurnal Biogenesis 8 (2012)

18. NKT. Martuti, Dinamika Logam Cu dalam Tambak Bandeng: Interaksi antara Media Lingkungan, Avicennia, marina dan Ikan Bandeng, Disertasi Program Doktor Ilmu Lingkungan Undip (2016)

19. N. Din, V.M. Ngo-Massou., G.L. Essomè-Koum, E. Ndema-Nsombo, E. Kottè-Mapoko, L. Nyamsi-Moussian, Impact of Urbanization on the Evolution of Mangrove Ecosystems in the Wouri River Estuary (Douala Cameroon), In: Finkl C., Makowski C. (eds) Coastal Wetlands: Alteration and Remediation. Coastal Research Library, 21 (2017)

20. G. Masselink, P. Russel, Impact of Climate Change on Coastal erosion, MCCIP Science Review, 71-86 (2013) 